\title{
Curcumin, A Potential Therapeutic Candidate for Anterior Segment Eye Diseases: A Review
}

\author{
Xiu-Fen $\mathrm{Liu}^{1 \dagger}$, Ji-Long Hao't, Tian Xie'2, Nour Jama Mukhtar', Wiley Zhang ${ }^{3}$, \\ Tayyab Hamid Malik', Cheng-Wei Lu ${ }^{1 *}$ and Dan-Dan Zhou ${ }^{5 *}$
}

'Department of Ophthalmology, The First Hospital of Jilin University, Changchun, China, ${ }^{2}$ Department of Neurosurgery, The People's Hospital of Jilin Province, Changchun, China, ${ }^{3}$ Department of Molecular Pathology, Icahn School of Medicine at Mount Sinai, Manhattan, NY, USA, ${ }^{4}$ Department of Gastroenterology, The First Hospital of Jilin University, Changchun, China, ${ }^{5}$ Department of Radiology, The First Hospital of Jilin University, Changchun, China

\section{OPEN ACCESS}

Edited by:

Adolfo Andrade-Cetto,

National Autonomous University

of Mexico, Mexico

Reviewed by:

Kayo Masuko,

Sanno Medical Center, Japan

Pinarosa Avato,

University of Bari, Italy

${ }^{*}$ Correspondence:

Cheng-Wei Lu

Icwchina800@sina.com

Dan-Dan Zhou

zhoudan0928@sohu.com

tThese authors are co-first authors.

Specialty section:

This article was submitted to

Ethnopharmacology,

a section of the journal

Frontiers in Pharmacology

Received: 17 November 2016

Accepted: 01 February 2017

Published: 14 February 2017

Citation:

Liu X-F, Hao J-L, Xie T, Mukhtar NJ,

Zhang W, Malik TH, Lu C-W and

Zhou D-D (2017) Curcumin,

A Potential Therapeutic Candidate

for Anterior Segment Eye Diseases:

A Review. Front. Pharmacol. 8:66.

doi: 10.3389/fphar.2017.00066
Curcumin, the major curcuminoid of the turmeric, has been extensively used in many countries since ancient time for preventing and/or treating a multitude of diseases. This review is to illustrate the researches on the properties of curcumin and its potential therapeutic efficacy in major anterior segment eye diseases. The bio-medical potential of curcumin is restricted because of its low solubility and digestive bioavailability. This review will discuss promising research in improving curcumin bioavailability through structural modification. In vitro and in vivo research made progress in studying the beneficial effects of curcumin on major anterior segment eye diseases, including antiangiogenesis effect in corneal diseases; anti-inflammation or anti-allergy effects in dry eye disease, conjunctivitis, anterior uveitis; anti-proliferation and pro-apoptosis effects in pterygium; anti-oxidative stress, anti-osmotic stress, anti-lipid peroxidation, pro-apoptosis, regulating calcium homeostasis, sequestrating free radicals, protein modification and degradation effects in cataracts; neuroprotective effects in glaucoma. Curcumin exhibited to be a potent therapeutic candidate for treating those anterior segment eye diseases.

Keywords: curcumin, corneal diseases, dry eye, conjunctivitis, anterior uveitis, pterygium, cataract, glaucoma

\section{INTRODUCTION}

Curcumin is a yellow-colored polyphenol that is isolated from the plant Curcuma-Longa and is the principal curcuminoid of the popular spice turmeric. It has been used in various curcuminbased products including energy drinks, ointments, capsules, tablets, soaps, cosmetics, and traditional medicines for centuries. Curcumin is extensively used as a supplement in China, India, USA, South Africa, Pakistan, Japan, Thailand, Korea, Siddha, and Chinese medicine for the management of various diseases and conditions, such as wounds, inflammation, and cancers (Strimpakos and Sharma, 2008; Aggarwal and Sung, 2009; Prasad et al., 2014). Curcumin has been considered as an effective drug for various respiratory conditions in traditional Chinese medicine, including allergy, asthma, bronchial hyperactivity and other disorders (sinusitis, coryza, cough, anorexia, and hepatic diseases) (Rahman et al., 2006). During the

Abbreviations: AR, Aldose reductase; CNLC, cationic nanostructured lipid carriers; GSH, Glutathione; GST, Glutathione $S$-transferase; IL-1 $\beta$, interleukin-1 beta; I/R, ischemia/reperfusion; LPO, Lipoperoxides; MMP, matrix metalloprotein; NF-кB, nuclear factor kappa-light-chain-enhancer of activated B cells; NPs, nanoparticles; NSAIDs, Non-Steroidal Antiinflammatory Drugs; NV, neovascularization; STZ, streptozotocin; TNF- $\alpha$, tumor necrosis factor- $\alpha$; VEGF, vascular endothelial growth factor. 
last three decades, various studies concluded that curcumin has anti-oxidant, anti-inflammatory, anti-angiogenic, and woundhealing effects (Maheshwari et al., 2006; Zhang et al., 2015).

The pathologic mechanisms of major blinding anterior segment eye diseases, such as corneal NV, glaucoma, and cataracts, are often related to inflammation, oxidative stressmediated response, and angiogenesis. There is substantial evidence that suggest the potential health benefits of curcumin in diets and drugs to prevent the vision threatening eye diseases (Huynh et al., 2013). This review summarizes the mechanisms underlying the effects of curcumin on anterior segment eye diseases.

\section{METHODOLOGY}

The PubMed database was searched with the terms "curcumin," "curcuminoid", "curcuminoids", "Curcuma longa," "turmeric", "haridra", "diferuloylmethane", and "eye", "ocular", either alone and in combination. Articles related with anterior segment eye diseases were picked out manually. All articles with English abstract were included, including those published in other language.

\section{BIOLOGICAL ACTIVITIES OF CURCUMIN}

Curcumin was discovered in 1815, and subsequently identified as 1,7-bis- (4-hydroxy-3-methoxyphenyl)-1,6- heptadiene-3, 5dione that exhibits keto-enoltautomerism, having an enol form in alkaline media and a keto form in neutral and acidic solutions (Anand et al., 2008). It is supposed to play an important role in many animal disease models. This polyphenol has been considered as an efficacious and safe agent in clinical trials, and curcumin has been approved as a "generally regarded as safe" compound by the U.S. Food and Drug Administration.

Anterior segment eye diseases include conjunctivitis associated with inflammation, cataracts associated with hyperglycemia and oxidative stress, pterygiums associated with excessive proliferation, and other diseases. Varieties of functions of curcumin have also been explored recently, including its anti-inflammatory effects, anti-oxidant activity, hypoglycemic effects, and anti-tumor (breast, prostate, lung, pancreas, ovary, bladder, cervix, head and neck, brain, kidney, and skin) effects (Chen et al., 2006; Strimpakos and Sharma, 2008; Prasad et al., 2014; Bimonte et al., 2015; Zhang et al., 2015) Curcumin can also induce cell death in human uveal melanoma cells through mitochondrial pathway (Lu et al., 2010). All of aforementioned bio-functions contribute to the potential beneficial effects of curcumin on anterior segment eye diseases.

\section{SYNTHETIC ANALOGS OF CURCUMIN IN OCULAR}

It is still considered a challenge for topical therapy to corneal diseases because tear fluids can wash the eye drops away rapidly (Joseph et al., 2016). At same time, the anatomical structure of the cornea causes a natural barrier for drug to penetrate through the cornea into anterior chamber (Chang et al., 2001). Though its safety and efficacy well-established, so far curcumin has not been applied as a therapeutic drug, perhaps, due to its relatively low aqueous solubility (Anand et al., 2007). However, a lot of reports mention that bioavailability might not be a problem. Different types of formulations that have been made with curcumin are to enhance bioavailability through various strategies. The thermo-sensitive gelling agent and nanogel combining CNLC has been designed to enhance the potentials for ocular permeation capacity of curcumin. The developed Curcumin-CNLC-GEL could significantly augment the bioavailability of curcumin and sustain drug concentration in aqueous humor after dispensation in comparison with that of the control group. Those results indicated that Curcumin-CNLC-GEL could become a potential formulation for the enhancement of solubility of curcumin in the aqueous humor by enhancing corneal diffusion and retaining capacity (Liu et al., 2016). Another study reported that methoxypoly (ethylene glycol)-poly ( $\varepsilon$-caprolactone) diblock copolymers (MePEG-PCL) nanoparticle of curcumin enhances retention of curcumin in the cornea, and improves corneal NV over curcumin (Pradhan et al., 2015). Jie et al. tested an ophthalmic in situ gel made of curcumin-loaded nanoparticles (Cur-BSA-NPs-Gel), and found that curcuminloaded albumin nanoparticles (Cur-BSA-NPs-Gel) scored superior sustained-release result, and concluded albumin nanoparticles (Cur-BSA-NPs-Gel) exhibit little effects on the gel structure in vitro. The in vivo study also indicated that the formulation might greatly increase bioavailability of the curcumin in the aqueous humor. Therefore, the curcuminloaded albumin nanoparticles (Cur-BSA-NPs-Gel) system depicted that an ophthalmic delivery system that may prolong drug retention time and enhanced ocular bioavailability (Lou et al., 2014). Ion-sensitive curcumin-loaded Pluronic P123 (P123)/D-a-tocopheryl polyethylene glycolsuccinate (TPGS) mixture of micelle in situ gels (CUR-MM-ISGs) prepared by $\mathrm{Yu}$ et al. prolonged ocular residence time and greatly enhanced cornea permeability, and these findings showed that the biocompatible CUR-MM-ISGs had significant potentials for effective ophthalmic drug therapy (Duan et al., 2015). A novel demethylated curcuminoid compositon exhibited superior anti-inflammatory and neuroprotective efficacy compared to curcuma longa extract. Demethylated curcuminoid composition was classified as mildly irritating to the eye based on the primary eye irritation test on rabbits (Krishnaraju et al., 2009). An adjunctive-to-traditional medicine with Norflo tablets (curcumin-phosphatidylcholine complex) was given two times a day in various recurrent anterior uveitis. It is illustrated that Norflo tablets was well endured and could potentially minimize ocular discomfort several weeks later in almost $80 \%$ of patients (Allegri et al., 2010). Other curcumin based formulation was also reported that are made to owing more biological activities than curcumin (Shoji et al., 2008; Liu et al., 2011; Das and Sahoo, 2012; Steigerwalt et al., 2012; Grama et al., 2013). 


\section{CURCUMIN AS A PROMISING THERAPEUTIC CANDIDATE FOR ANTERIOR SEGMENT EYE DISEASES}

\section{Cornea Diseases}

\section{Inhibiting Corneal NV}

The cornea is the transparent avascular anterior part of the eye. Corneal NV is a condition in which excessive blood vessels grow into the cornea and is the leading cause of blindness. This condition is trigged by corneal hypoxia, inflammation, and/or limbal barrier dysfunction. Currently, the treatments for corneal $\mathrm{NV}$ include steroids, nonsteroidal anti-inflammatory eye drops, fine needle diathermy, photodynamic therapy, and anti-VEGF therapy (Chang et al., 2001). Though, these therapies ameliorate corneal NV to some extent, the side effects cannot be ignored: steroids may cause corneal thinning, ocular hypertension, and cataracts (Sarchahi et al., 2008); NSAIDs may lead to corneal ulceration and perforation (Guidera et al., 2001); fine needle diathermy and photodynamic therapy may cause an inflammatory response (Shakiba et al., 2009; Koenig et al., 2012); and anti-VEGF therapy complications include corneal thinning, reduced epithelial healing (Kim et al., 2008), and epithelial erosion (Oh et al., 2009). Therefore, a safe and effective therapy for corneal NV is needed.

Vascular endothelial growth factor and basic fibroblast growth factor (bFGF) are supposed to attract and recruit inflammatory cells, leading to corneal NV. Curcumin could inhibit proliferation of primary endothelial cells cultured in vitro, either in the presence or absence of bFGF (Arbiser et al., 1998). It was able to prohibit bFGF-induced mouse corneal NV in vivo (Arbiser et al., 1998). Suturing-induced rabbit corneal NV could also be suppressed by curcumin, in vivo (Kim et al., 2010) via decreasing the VEGF mRNA levels and phosphorylation of NF- $\kappa$ B (Kim et al., 2010). Curcumin NPs might significantly reduce angiogenic sprouting in a dose and time dependent manner in the mouse aortic ring in vitro. Curcumin NPs were also able to inhibit NF- $\kappa$ B in LPS-induced corneal cells in vitro (Pradhan et al., 2015). It may also prohibit corneal angiogenesis in silver nitrate-induced corneal NV in vivo through the mechanism of inhibiting VEGF, inflammatory cytokines [IL-1 $\beta$, TNF- $\alpha$ ], and MMPs (MMP-2 and MMP-9) (Pradhan et al., 2015). Curcuminoids, administered locally or in the diet, could suppress fibroblast growth factor-2 (FGF-2)-induced rabbit corneal NV in vivo, by inhibiting DNA binding activity from transcription factor activator protein-1 (AP-1) and gelatinase B promoter activity (Mohan et al., 2000). The effects and mechanisms of curcumin and curcumin NPs on corneal diseases warrant an effective and safe herbal therapy for preventing corneal NV (Figure 1).

\section{Protecting Corneal Epithelial Barrier}

The corneal epithelium provides a strict barrier that is both useful for dependent on tight junctions between adjacent epithelial cells and corneal homeostasis. Barrier function of the corneal epithelium can be undermined by bacterial infection or inflammation, resulting in different conditions of the epithelium and in stromal edema, infection, or melting. Kimura et al. (2008) found that TNF- $\alpha$ or IL-1 $\beta$ could damage the human corneal epithelial cells barrier in vitro by affecting the localization of the tight junctions proteins zonula occludens-1 at tight junctions dependent on NF- $\kappa$ B. Curcumin could inhibit both TNF- $\alpha$ and IL- $1 \beta$ induced subcellular localization of occludens- 1 through $\mathrm{NF}-\kappa \mathrm{B}$ inhibition in vitro, indicating curcumin may prevent corneal epithelial barrier function disruption related with ocular inflammation (Kimura, 2010).

\section{Promoting Corneal Wound Healing}

Diabetes increases the risk of corneal diseases, and as high as 50\% of diabetic patients suffered from diabetic keratopathy (Zagon et al., 2007), including reduced corneal sensitivity, decreased tear secretion, tear film dysfunction, degeneration of nerve fibers, loss of corneal epithelia, and corneal ulcer (Gao et al., 2015). The current treatments for diabetic keratopathy include artificial tears, antibiotic eye drops, tarsorrhaphy, and bandage contact lens, which helps for corneal wound healing (Abdelkader et al., 2011). However, these measures may not be effective and adequate at accelerating re-epithelialization in diabetes, even if different therapies are used simultaneously. Thus, novel effective methods are required.

Guo et al. reported intranasal nanomicelle curcumin promotes corneal epithelial/nerve wound healing in STZ-induced diabetic mice with corneal epithelium abrasion. The mechanism includes alleviating free radical scavengers, recovering the enhanced accumulation of reactive oxygen species (ROS), decreased mRNA expressions of neurotrophic factors, and increased mRNA expressions of inflammatory cytokines in the cornea. Trigeminal ganglion neurons were also observed in mice with corneal epithelium abrasions. These findings illustrate that intranasal curcumin could effectively promote diabetic corneal epithelial or nerve wound healing. This treatment might be a promising therapy for diabetic keratopathy (Guo et al., 2016).

\section{Dry Eye Disease}

Dry eye disease is one of the most prevalent eye diseases, with an estimated ten million individuals affected in the United States (Niederkorn et al., 2006). Decreased secretion of the tears and rapid tear evaporation are the two contributing factors for dry eye disease. Increased tear osmolality and ocular surface inflammation are involved in the pathogenesis of ocular surface damage during the course of the disease. Different types of antiinflammatory drugs like topical corticosteroid usually improve the symptoms of the disease in short term trials (Yang et al., 2006). Unfortunately, in the long run, some serious potential side effects limit its use (Lemp, 2007). So far, all the available drugs have some limitations, which call for the need to develop more potent drugs for the treatment of dry eye disease. The possible mechanisms of curcumin on dry eye disease are still unclear. Increased tear osmolality is an important feature of the disease. In a hyperosmotic environment, pro-inflammatory cytokines such as interleukin-6 (IL-6), interleukin-8 (IL-8), and IL-1 $\beta$ are detected in corneal cell lines or dry eye patients (Solomon et al., 2001; Li et al., 2006; Chotikavanich et al., 2009). Curcumin could inhibit ovalbumin-induced pro inflammatory cytokines [interleukin-4 (IL-4), interleukin-5 (IL-5)] expression 


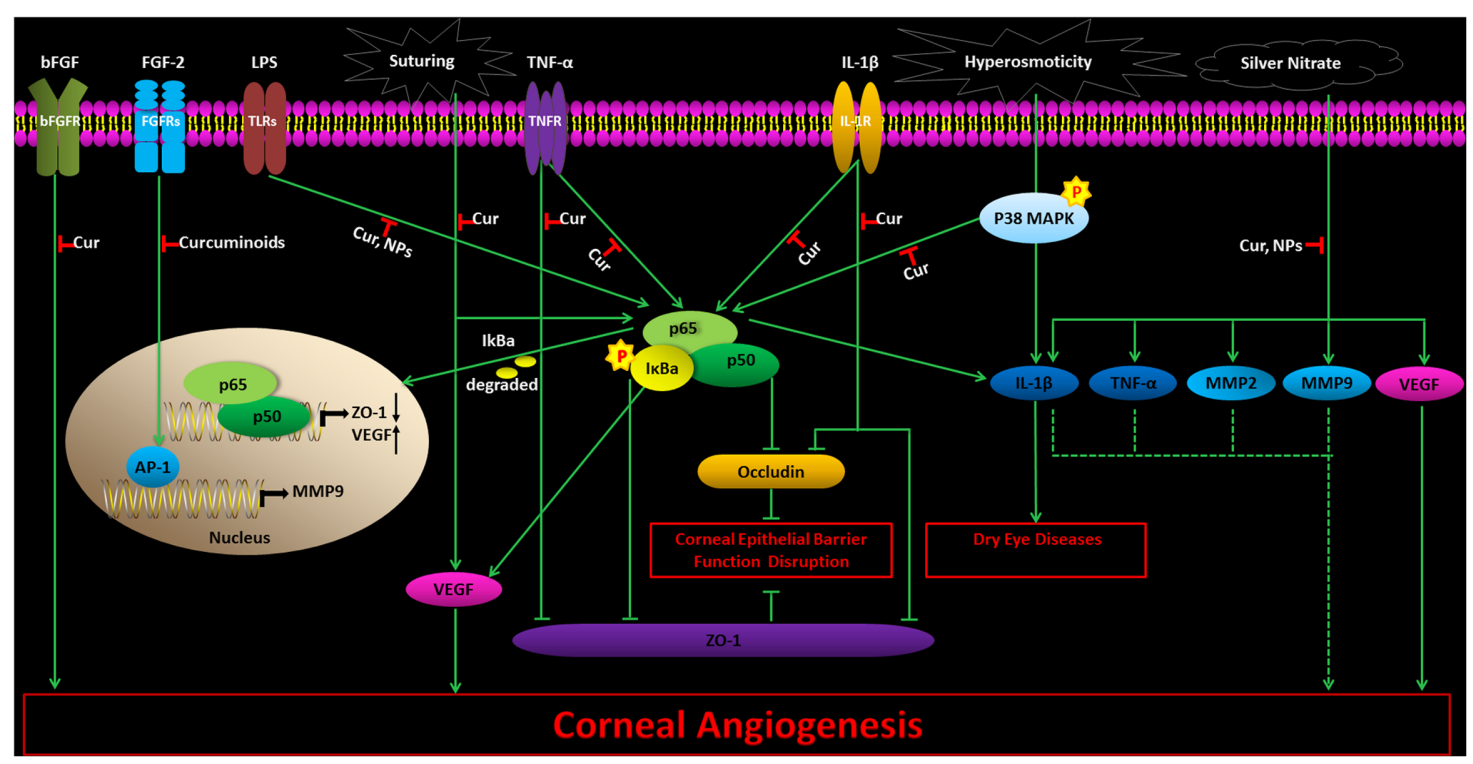

FIGURE 1 | The effects and mechanisms of curcumin and curcumin NPs on corneal diseases. Cur, Curcumin; NPS, curcumin nanoparticles. Thin arrows show direct reactions, and dotted arrows indicate indirect reactions.

in conjunctiva in mice (Chung et al., 2012). Our previous study showed that curcumin guarded against hyperosmoticity-induced IL-1 $\beta$ upregulation in corneal epithelial cell in vitro through p38 mitogen-activated protein kinase (MAPK)/NF- $\kappa \mathrm{B}$ pathways (Chen et al., 2010), which indicates that curcumin might serve as a promising candidate for treating dry eye disease.

\section{Conjunctivitis}

Conjunctivitis is one of the most frequently occurring ocular diseases worldwide. It can be caused by bacteria, viruses, and allergies. Conjunctivitis is becoming increasingly prevalent due to the resilient bacterial strain infections, changing climate, increased pollen loads, pollution, and the resulting heightened immunological response to the environmental changes. There are many ocular medications for treating conjunctivitis but they are expensive and the long treatment period increases the risk of microbial resistance. An inexpensive and low side-effect treatment is needed, especially in developing countries.

Ophthacare, obtained from the Himalaya Drug Company, is the brand name of a mixed herbal eye drop with 8 different herbs, - including curcuma-longa (rhizome) $1.30 \% \mathrm{w} / \mathrm{v}$ was reported to have positive effects to treat conjunctivitis, conjunctival xerosis (dry eye), etc. (Biswas et al., 2001). In a previous study, it was reported to have effects in different ophthalmic diseases namely, conjunctivitis, conjunctival xerosis (dry eye), etc. (Biswas et al., 2001). The study showed that OphthaCare can be safely administered in various infective and inflammatory conjunctival diseases, but has still yet to be assessed in a double-blind clinical trial. Haridra (Curcuma-Longa) is available freely in India and in tropics, and Haridra Eye Drops was reported to have an important role in treating bacterial conjunctivitis in a clinical study. Bacteriological study shows the Haridra has an active role against Escherichia coli (E. coli),
St. Aureus, Klebshella, and pseudomonas organisms (Srinivas and Prabhakaran, 1989). Curcumin was reported to suppress ovalbumin-induced allergic conjunctivitis in an experimental mice model (Chung et al., 2012). Mice challenged with ovalbumin via the conjunctival sac following systemic sensitization in aluminum hydroxide had severe allergic conjunctivitis. Preadministration of curcumin $1 \mathrm{~h}$ before ovalbumin challenge could markedly inhibit the activation of inducible nitric oxide synthase (iNOS) production in the mice conjunctiva and suppress immunoglobulin E (IgE)-mediated and eosinophildependent conjunctival inflammation. Inhibition of IL-4 and IL5 expression in conjunctiva, cervical lymph nodes, and spleen was observed in mice treated with curcumin, when compared to mice challenged with ovalbumin. These results indicate that curcumin suppresses allergic conjunctivitis through its anti-allergic and anti-inflammation properties.

\section{Pterygium}

Pterygium is an inflammatory and degenerative ocular surface disease in which the conjunctiva on the cornea grows to form fibrous tissue in a triangular shape. The pathogenesis is not completely understood, but recent evidence suggests that pterygium is histologically composed of proliferating fibro vascular tissue and is correlated strongly with exposure to ultraviolet radiation (Yam and Kwok, 2014; Shah et al., 2016). Surgical excision is the first-choice treatment for pterygium, but the high recurrence rate is a burden for patients. Therefore, the treatment of pterygium remains quite controversial. The identification of effective drugs for the treatment of pterygium is urgently needed. Curcumin $(20-80 \mu \mathrm{mol} / \mathrm{L})$ was found to hinder the expression of spreading cell nuclear antigen and to stop the proliferation and cause the cell death of human pterygium fibroblasts both in a dose-and time-dependent 
manner, indicating that curcumin had a potential therapeutic outcome against pterygium (Zhang et al., 2007). However, the study was restricted to in vitro experiment. Biswas et al. (2001) documented that OphthaCare showed an excellent response in the treatment of pterygium.

\section{Anterior Uveitis}

Anterior uveitis is associated with inflammation of the uveal tract (especially the iris) and without intervention can cause blurry vision and permanent damage to the eye. It is the fourth most common cause of blindness in developed countries (Chang and Wakefield, 2002; Merida et al., 2015). The underlying mechanism of uveitis is unclear due to its heterogeneity. Corticosteroid and NSAIDs are the main available treatment for uveitis. However, side-effects (i.e., cataract, secondary glaucoma, anterior, and posterior synechiae) are commonly observed with steroid therapy. Corticosteroid can only provide some shortterm relief, but not significant long-term relief. An alternative therapeutic that could relieve inflammation like a corticosteroid, but without any adverse side effects is needed.

It was reported that curcumin could treat chronic anterior uveitis without any adverse side effects (Lal et al., 1999). Curcumin was filled in capsules (375 $\mathrm{mg}$ curcumin/capsule) and taken orally by patients with chronic anterior uveitis. Patients took one capsule t.i.d. along with local cyclopegics (e.g., atropine/cyclopentolate1\%) improved their vision significantly with decreased aqueous flareand keratic precipitates (Lal et al., 1999).

Meriva (Indena, Milano, Italy) is a product-curcumin formulated with phosphatidylcholine-which improves bioavailability at least 10 times compared to standard curcumin (Marczylo et al., 2007). It exhibited a beneficial effect in the adjunctive therapy of recurrent anterior uveitis with different etiologies, including herpetic (cytomegalovirus, Epstein-Barr virus, varicella zoster virus, and herpes simplex virus) uveitis, autoimmune (overlap syndrome, sarcoidosis, rheumatoid arthritis, and systemic lupus erythematosus) inflammatory ocular disease, and different origin anterior uveitis (seven toxoplasmic etiology, eight unknown origin, four Lyme disease, and three tuberculosis), with the most sensitive being for autoimmune uveitis, and more relapsing against herpetic uveitis (Allegri et al., 2010). Various mechanisms for these beneficial effects of curcumin have been proposed. Topically applied standardized aqueous extract of Curcuma-Longa suppresses E. coli lipopolysaccharide-induced anterior uveitis in rats (Agarwal et al., 2013) and rabbits (Gupta et al., 2008) by reducing TNF- $\alpha$ activity (Agarwal et al., 2013). Curcumin may also stabilize the lysosomal membranes (Srivastava and Srimal, 1985; Dikshit et al., 1995), inhibit leukotrienes (Flynn et al., 1986; Ammon et al., 1992) and thromboxane B4 (Srivastava and Srimal, 1985). It possesses strong free radical scavenging (Zhao et al., 1989) and anti-oxidant properties (Rajakumar and Rao, 1994). It was found to prompt nitric oxide synthesis in activated macrophages and to inhibit neutrophil activity (Brouet and Ohshima, 1995). Its beneficial effect may be related to the anti-fibrinolytic activity for breaking the anterior and the posterior synechiae (Lal et al., 1999).
Compared with corticosteroids, curcumin exhibits an advantage in lacking adverse side effects in the treatment of chronic anterior uveitis.

\section{Cataract}

Cataracts accounts for more than one third of blindness globally (Resnikoff et al., 2008). Twenty-five percent of people over the age of 65 and $50 \%$ of people over the age of 80 have a serious loss of vision due to cataracts (Foster and Resnikoff, 2005). Cataract extraction surgery is the mainstream treatment for cataract. While cataract surgery is considered to be safe and mature, irreversible blindness is a potential risk. There is no recognized medication which can cure or reverse cataract. If cataract onset is delayed by 10 years, it is estimated to reduce the possibility for cataract surgery by $50 \%$ (Kupfer, 1985). Thus, much emphasis is being laid on identifying compounds with high effectiveness and low toxicity that can either prevent the onset or delay cataract progression.

\section{Anti-oxidative Stress}

It is believed that oxidative damage to the eye lens contributes to the development of different kinds of cataracts (Suryanarayana et al., 2005; Manikandan et al., 2010a,b). The primary mechanism for the anti-cataract effect of curcumin is through its antioxidant properties (Manikandan et al., 2009, 2010a, 2011; Radha et al., 2012).

Curcumin may inhibit peroxiredoxin 6 (a pleiotropic oxidative stress-response protein) in cultured human lens epithelial cells (hLECs) in vitro (Chhunchha et al., 2011). Bioactive derivatives of curcumin (salicylidenecurcumin CD1 and benzalidenecurcumin $\mathrm{CD} 2$ ) were reported to inhibit the selenite induced cataract by reversing the activity of antioxidant enzymes, decreasing ROS, and increasing the activities of superoxide dismutase (SOD) (Manikandan et al., 2010a; Radha et al., 2012).

Curcumin was found to have a protective effect against cataract development and/or progression in numerous in vitro and in vivo cataract models (Awasthi et al., 1996; Pandya et al., 2000; Suryanarayana et al., 2003, 2005; Kumar et al., 2005a,b; Raju et al., 2006; Manikandan et al., 2009, 2010a,b, 2011; Grama et al., 2013). It may suppress selenium-induced oxidative stress in rat organ cultured lens and delay the formation of cataracts by inhibiting the non-enzymic antioxidants depletion (Manikandan et al., 2009). Vitamin C is a potent non-enzymic antioxidant, and the level of Vitamin $\mathrm{C}$ is high in human lens, suggesting that vitamin $\mathrm{C}$ may have a preventive role in cataract progression. The decreased vitamin $\mathrm{C}$ levels observed in selenite-induced rat cataracts suggests that weakened nonenzymatic antioxidant defenses may play a role in seleniteinduced rat cataracts. Administration of curcumin was found to increase vitamin C levels (Murugan and Pari, 2006). Pretreatment of curcumin may prevent oxidative damage and delay the development of cataracts by increasing superoxidase dismutase and catalase enzyme activity in Wistar rats (Padmaja and Raju, 2004). Curcumin may prevent alterations of protein carbonyls, antioxidant enzymes glutathione peroxidase (GPx), glucose-6phosphate dehydrogenase (G6PD) and significantly decreased 
GSH levels, demonstrating curcumin delay the progression of diabetic cataract by preventing hyperglycemia-mediated lenticular oxidative stress in rats (Suryanarayana et al., 2005).

\section{Anti-lipid Peroxidation Stress}

Lipoperoxides is enhanced in selenite-induced rat cataract in vivo (Manikandan et al., 2010b). Hiobarbituric acid-reacting substances (TBARS), commonly measured as a marker of LPO, was also elevated in rat of selenite-induced and STZ-induced cataract in vivo (Suryanarayana et al., 2005; Manikandan et al., 2010b), indicating enhanced lipid peroxidation in cataracts. Curcumin significantly delayed the progression and maturation of cataracts in a dose-dependent manner by decreasing LPO and TBARS (Suryanarayana et al., 2005; Manikandan et al., 2010b). GST is a group of multifunctional proteins that performs tasks ranging from catalyzing the detoxification of electrophilic compounds to protecting against peroxidative damage (Sener et al., 1979). GST is decreased in selenite-induced rat cataracts in vivo, and curcumin increased the activity of GST to near normal level (Manikandan et al., 2010b). 4-hydroxy-2transnonenal (4-HNE) is a highly electrophilic product of lipid peroxidation. It was reported that curcumin has a protective effect on organ-cultured lens in 4-HNE induced cataract formation. Curcumin treatment caused an induction of the GST isozymer GST8-8 in rat lenticular epithelium. GST8-8 uses 4$\mathrm{HNE}$ as a favorable substrate, suggesting the beneficial effect of curcumin may be regulated by producing this GST isozyme (Suryanarayana et al., 2005; Manikandan et al., 2010b). GSH is believed to prevent the cells from lipid peroxidation. GSH is known as a free radical scavenger, a cofactor for many enzymes and a co-substrate for glutathione peroxidase (GPx) activity (Gregus et al., 1996). Selenite increases lipid peroxidation in rat lens, leading to downregulation of GSH in the lens. Curcumin pretreatment resulted in maintaining normal GSH levels that was detected in tissues and serums in selenite treated lenses in vivo, indicating the protective role of curcumin against oxidative stress (Manikandan et al., 2010b).

Vitamin E, a natural lipid soluble antioxidant, can maintain the integrity of cell membrane and vital membrane functions by inhibiting lipid peroxidation. Vitamin $\mathrm{E}$ was reported to have a protective effect in delaying galactose-induced cataract formation and aminothiazole-induced cataract formation in rabbits, inhibiting the lipid photo-peroxidation in lens, limiting radiation related lenticular damage, and preventing diabetic cataract or heat-induced cataract formation (Creighton et al., 1985; Gregus et al., 1996). The level of vitamin $\mathrm{E}$ in lens homogenate was decreased in rat treated with selenite alone, and early administration of curcumin produced a protective effect on vitamin E levels (Manikandan et al., 2010b). Curcumin in a $0.01 \%$ dose, supplemented with vitamin-E, inhibited galactose-induced rat cataract in vivo by inhibiting lipid peroxidation (Raju et al., 2006).

\section{Anti-osmotic Stress}

Aldose reductase, a vital enzyme for polyol pathway, was significantly increased in STZ-induced diabetic rat lens. Curcumin normalized AR activity in vivo, indicating curcumin is effective against osmotic stress caused by hyperglycemia (Suryanarayana et al., 2005; Grama et al., 2013).

\section{Protein Modification and Degradation}

Studies have shown that even in the earliest stages of cataract formation, the pattern of lens proteins changed (Manikandan et al., 2010a). Significant decreases were found in $\beta$ crystallins, gamma $(\gamma)$-crystallins, and a high molecular weight (HMW) aggregate peak in STZ-induced diabetic rat lens by High Performance Liquid Chromatography (HPLC). The proportion of cross-linked and aggregated proteins were detected to be increased in the soluble protein in STZ-induced diabetic rat lens, suggesting either aggregation or cross-linking might or any unknown factor might be causing protein modification and degradation in diabetic cataractous lens, leading to the formation of HMW aggregates. The insolubility of otherwise soluble protein and alterations in protein profile can result in lens opacification (Kumar et al., 2005b; Suryanarayana et al., 2005). Curcumin and turmeric remarkable alleviated those protein changes, indicating that curcumin and turmeric has a protective effect against diabetic cataract in rats (Kumar et al., 2005b; Suryanarayana et al., 2005). Heat shock protein 70 (Hsp 70), $\alpha$ A-crystalline, $\alpha \mathrm{B}$-crystallin were the predominant constituent proteins which maintain eye lens transparency, and were increased in cataracts. Curcumin could suppress the expression of Hsp 70, aAcrystalline, and $\alpha \mathrm{B}$-crystallin in STZ or selenite-induced cataracts in rat. (Kumar et al., 2005a; Manikandan et al., 2011).

\section{Calcium Homeostasis}

Although the precise mechanisms of cataracts are not fully elucidated, a plausible mechanism might be that constant oxidative stress causes progressive deterioration of $\mathrm{Ca}^{2++}$ homeostasis (Hightower and McCready, 1989). $\mathrm{Ca}^{2+}$ is essential for maintenance of lens transparency, and increased $\mathrm{Ca}^{2+}$ could activate calpain which can degrade crystallins in lens, leading to cataract formation (Shearer and David, 1982; Thiagarajan and Manikandan, 2013). It was reported that $\mathrm{Ca}^{2+}$ ATPase may participate in regulating $\mathrm{Ca}^{2+}$ homeostasis in lens (Manikandan et al., 2010a). Curcumin may decrease selenite-induced increase of $\mathrm{Ca}^{2+}$ concentration in selenium-induced rat cataract model in vivo by increasing the activities of $\mathrm{Ca}^{2+}$ ATPase and thus lowering the $\mathrm{Ca}^{2+}$ to an almost normal level (Manikandan et al., 2010a).

\section{Anti-nitrosative Stress and Scavenge Free Radicals}

Excessive free radical generation $\left(\mathrm{NO}, \mathrm{OH}^{-}, \mathrm{O}^{2-}\right.$ ) has been identified as one of the major etiological factors of cataracts (Spector, 1995). An excess of NO, produced by inducible nitric oxide synthases (iNOS), is thought to cause cell injury by nitrosative stress and contribute to cataract formation (Ito et al., 2001; Ornek et al., 2003; Manikandan et al., 2010a). $\mathrm{OH}^{-}$ is also a highly reactive free radical that contributes to lens crystalline modification ( $\mathrm{Fu}$ et al., 1998). $\mathrm{OH}^{-}$could react with NO, generating more reactive compounds (Graham et al., 1993). Curcumin has been reported to be able to sequestrate free radicals, and scavenge $\mathrm{NO}, \mathrm{OH}^{-}, \mathrm{O}^{2-}$ in isolated rat peritoneal macrophage in vitro (Joe and Lokesh, 1994). Curcumin 
TABLE 1 | Selected observational studies on the relationship between curcumin and cataract models.

\begin{tabular}{|c|c|c|c|c|}
\hline Type & Models & Oberservation & Results & Reference \\
\hline \multirow[t]{5}{*}{ In vitro } & Cultured human LEC & $\begin{array}{l}\text { Effect of curcumin on } \\
\text { peroxiredoxin } 6 \text { in } \\
\text { ROS-induced oxidative } \\
\text { stress-response in human LEC }\end{array}$ & $\begin{array}{l}\text { Curcumin protects LEC by upregulating peroxiredoxin } 6 \text { transcription via } \\
\text { invoking specificity protein } 1 \text { (Sp1) activity against proapoptotic stimuli. }\end{array}$ & $\begin{array}{l}\text { Chhunchha } \\
\text { et al., } 2011\end{array}$ \\
\hline & Cultured bovine LEC & $\begin{array}{l}\text { Effect of curcumin on apoptosis } \\
\text { of LEC }\end{array}$ & $\begin{array}{l}\text { Curcumin induced apoptosis of LEC by decreasing of DNA content in } \\
\text { LEC nucleus and collapsing of DeltaPsim in cytoplasm. }\end{array}$ & $\begin{array}{l}\text { Huang et al., } \\
2006\end{array}$ \\
\hline & Rat organ cultured lens & $\begin{array}{l}\text { Effect of curcumin and its } \\
\text { derivatives (CD1, CD2) on } \\
\text { selenite-induced cataract }\end{array}$ & $\begin{array}{l}\text { Curcumin and its derivatives (CD1, CD2) are beneficial against } \\
\text { selenite-induced cataract by reversing the activity of antioxidant } \\
\text { enzymes and calcium homeostasis to near normal levels in lens. }\end{array}$ & $\begin{array}{l}\text { Radha et al., } \\
2012\end{array}$ \\
\hline & Rat organ cultured lens & $\begin{array}{l}\text { Effect of curcumin on } \\
4 \text {-HNE-induced opacification of } \\
\text { lens }\end{array}$ & $\begin{array}{l}\text { Lens from diatary curcumin-treated rats were much more resistant to } \\
4-\mathrm{HNE} \text {-induced opacification than control group. }\end{array}$ & $\begin{array}{l}\text { Awasthi et al., } \\
1996\end{array}$ \\
\hline & Rat organ cultured lens & $\begin{array}{l}\text { Effect of curcumin on } \\
\text { selenium-induced oxidative } \\
\text { stress in lens }\end{array}$ & $\begin{array}{l}\text { Curcumin suppressed oxidative stress and cataract formation, } \\
\text { prevented uncontrolled generation of free radicals, and inhibited iNOS } \\
\text { expression. }\end{array}$ & $\begin{array}{l}\text { Manikandan } \\
\text { et al., } 2009\end{array}$ \\
\hline \multirow[t]{11}{*}{ In vivo } & $\begin{array}{l}\text { Selenium-induced rat } \\
\text { cataract }\end{array}$ & $\begin{array}{l}\text { Effect of curcumin on } \mathrm{Ca}^{2+} \\
\text { ATPase in selenium-induced } \\
\text { cataract }\end{array}$ & $\begin{array}{l}\text { Diatary curcumin prevented selenium-induced } \mathrm{Ca}^{2+} \text { ATPase activation } \\
\text { and inhibited cataract. }\end{array}$ & $\begin{array}{l}\text { Manikandan } \\
\text { et al., } 2010 a\end{array}$ \\
\hline & $\begin{array}{l}\text { Selenium-induced rat } \\
\text { cataract }\end{array}$ & $\begin{array}{l}\text { Effect of curcumin on } \alpha \mathrm{A} \text { - and } \\
\alpha \mathrm{B} \text {-crystallin and heat shock } \\
\text { protein } 70 \text { in selenite-induced } \\
\text { cataract }\end{array}$ & $\begin{array}{l}\text { Diatary curcumin decreased selenium-induced the } \alpha \mathrm{A} \text { - and } \\
\alpha \mathrm{B} \text {-crystallin and Hsp } 70 \text { production. }\end{array}$ & $\begin{array}{l}\text { Manikandan } \\
\text { et al., } 2011\end{array}$ \\
\hline & $\begin{array}{l}\text { Selenium-induced rat } \\
\text { cataract }\end{array}$ & $\begin{array}{l}\text { Antioxidant effect of curcumin } \\
\text { on selenium-induced cataract }\end{array}$ & $\begin{array}{l}\text { Dietary curcumin prevented oxidative damage and delay the } \\
\text { development of cataract by attenuating lipid peroxidation, xanthine } \\
\text { oxidase enzyme activity and increasing superoxidase dismutase and } \\
\text { catalase enzyme activity. }\end{array}$ & $\begin{array}{l}\text { Padmaja and } \\
\text { Raju, } 2004\end{array}$ \\
\hline & $\begin{array}{l}\text { Selenite-induced rat } \\
\text { cataract }\end{array}$ & $\begin{array}{l}\text { Antioxidant effect of curcumin } \\
\text { on selenite-induced cataract }\end{array}$ & $\begin{array}{l}\text { Diatary curcumin decreased LPO, enzymic antioxidants, and } \\
\text { nonenzymic antioxidants induced by selenite. }\end{array}$ & $\begin{array}{l}\text { Manikandan } \\
\text { et al., } 2010 \mathrm{~b}\end{array}$ \\
\hline & $\begin{array}{l}\text { Naphthalene-induced } \\
\text { rat cataract }\end{array}$ & $\begin{array}{l}\text { Effect of curcumin on } \\
\text { naphthalene-induced } \\
\text { opacification of lens }\end{array}$ & $\begin{array}{l}\text { Dietary curcumin alleviated naphthalene-induced cataract by } \\
\text { attenuating apoptotis of LECs. }\end{array}$ & $\begin{array}{l}\text { Pandya et al., } \\
2000\end{array}$ \\
\hline & $\begin{array}{l}\text { Galactose-induced rat } \\
\text { cataract }\end{array}$ & $\begin{array}{l}\text { Effect of curcumin on } \\
\text { galactose-induced cataract }\end{array}$ & $\begin{array}{l}\text { Diatary curcumin delayed the onset and maturation of cataract by } \\
\text { antioxidant and antiglycating effects, as it inhibited lipid peroxidation, } \\
\text { AGE-fluorescence, and protein aggregation. }\end{array}$ & $\begin{array}{l}\text { Suryanarayana } \\
\text { et al., } 2003\end{array}$ \\
\hline & $\begin{array}{l}\text { Galactose-induced rat } \\
\text { cataract }\end{array}$ & $\begin{array}{l}\text { Effect of vitamin-E and } \\
\text { curcumin on galactose-induced } \\
\text { cataract }\end{array}$ & $\begin{array}{l}\text { Combination of diatary vitamin-E and curcumin delayed the on the } \\
\text { onset and maturation of galactose-induced cataract with an antioxidant } \\
\text { effect, as it inhibited lipid peroxidation and contributed to a distinct rise } \\
\text { in reduced GSH content. }\end{array}$ & $\begin{array}{l}\text { Raju et al., } \\
2006\end{array}$ \\
\hline & $\begin{array}{l}\text { STZ-induced rat } \\
\text { diabetic cataract }\end{array}$ & $\begin{array}{l}\text { Effect of curcumin and its } \\
\text { source (turmeric) on } \\
\text { STZ-induced diabetic cataract }\end{array}$ & $\begin{array}{l}\text { Dietary curcumin delayed the progression of cataract, with reversed } \\
\text { change in lipid peroxidation, reduced GSH, protein carbonyl content } \\
\text { and activities of antioxidant enzymes, preventing aggregation and } \\
\text { insolubilization of lens proteins due to hyperglycemia. }\end{array}$ & $\begin{array}{l}\text { Suryanarayana } \\
\text { et al., } 2005\end{array}$ \\
\hline & $\begin{array}{l}\text { STZ-induced rat } \\
\text { diabetic cataract }\end{array}$ & $\begin{array}{l}\text { Effect of curcumin NPs on } \\
\text { STZ-induced diabetic cataract }\end{array}$ & $\begin{array}{l}\text { Oral nanocurcumin was effective than curcumin in delaying diabetic } \\
\text { cataracts in rats, attributed to its ability to intervene protein } \\
\text { insolubilization, polyol pathway, protein glycation, crystallin distribution, } \\
\text { and oxidative stress. }\end{array}$ & $\begin{array}{l}\text { Grama et al., } \\
2013\end{array}$ \\
\hline & $\begin{array}{l}\text { STZ-induced rat } \\
\text { diabetic lens }\end{array}$ & $\begin{array}{l}\text { Effect of curcumin on } \alpha \mathrm{A} \text { - and } \\
\alpha \mathrm{B} \text {-crystallins in lens }\end{array}$ & $\begin{array}{l}\text { Dietary curcumin attenuated the enhanced expression of } \alpha \text { B-crystallin in } \\
\text { lens induced by STZ. }\end{array}$ & $\begin{array}{l}\text { Kumar et al., } \\
2005 a\end{array}$ \\
\hline & $\begin{array}{l}\text { STZ-induced rat } \\
\text { diabetic lens }\end{array}$ & $\begin{array}{l}\text { Effect of curcumin on } \\
\alpha \text {-crystallin chaperone activity in } \\
\text { lens }\end{array}$ & $\begin{array}{l}\alpha \mathrm{H} \text { - and } \alpha \mathrm{L} \text {-crystallins isolated from curcumin fed diabetic rat lens had } \\
\text { shown improved chaperone-like activity as compared to control group. }\end{array}$ & $\begin{array}{l}\text { Kumar et al., } \\
2005 b\end{array}$ \\
\hline
\end{tabular}

LEC, lens epithelial cells; STZ, Streptozotocin.

prevented uncontrolled generation of free radicals by inhibiting the production of iNOS in selenium-stimulated organ cultured lens of rat pups in vitro (Manikandan et al., 2009). Pretreatment of curcumin was found to prevent free radical generation in selenium-induced cataract in rat pups in vivo (Manikandan et al., 2010a).

\section{Inhibit Proliferation and Induce Apoptosis}

Lens cell membrane damage is considered as one of the early signs of cataractogenesis, resulting in changes in intraocular metabolism and composition (Vrensen, 1995). Suppressing the proliferation and inducing apoptosis of lens epithelial cells is the primary goal in preventing cataractogenesis. Curcumin 
TABLE 2 | Selected observational studies on the relationship between curcumin and anterior segment eye diseases.

\begin{tabular}{|c|c|c|c|c|}
\hline Region & Models & Oberservation & Results & Reference \\
\hline \multirow[t]{8}{*}{ Cornea } & Cultured HCE & $\begin{array}{l}\text { Effect of curcumin on TNF- } \alpha \\
\text { induced corneal barrier } \\
\text { disruption }\end{array}$ & $\begin{array}{l}\text { Curcumin blocked the TNF- } \alpha \text { induced occludens-1 } \\
\text { disappearance by suppressing the NF-kB pathway, and } \\
\text { it also blocked TNF- } \alpha \text { decreased TER. }\end{array}$ & Kimura et al., 2008 \\
\hline & Cultured HCE & $\begin{array}{l}\text { Effect of curcumin on IL-1 } \beta \\
\text { induced corneal barrier } \\
\text { disruption }\end{array}$ & 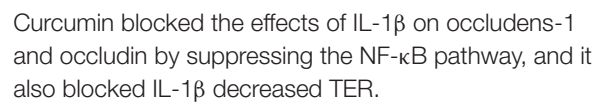 & Kimura et al., 2009 \\
\hline & Cultured HCE & $\begin{array}{l}\text { Effect of curcumin on dry eye } \\
\text { disease }\end{array}$ & $\begin{array}{l}\text { Curcumin inhibited hyperosmoticity-induced IL-1 } \\
\text { elevation in HCE through P38 MAPK/NF-кB pathways. }\end{array}$ & Chen et al., 2010 \\
\hline & $\begin{array}{l}\text { Mouse model of corneal NV, } \\
\text { cultured bovine capillary } \\
\text { endothelial cells, MS1 } \\
\text { endothelial cells line }\end{array}$ & $\begin{array}{l}\text { Effect of curcumin on the } \\
\text { proliferation of endothelial cells } \\
\text { with bFGF, and bFGF-induced } \\
\text { corneal NV. }\end{array}$ & $\begin{array}{l}\text { Curcumin inhibited bFGF-induced corneal NV in the } \\
\text { mouse cornea and both endothelial cells' proliferation. }\end{array}$ & Arbiser et al., 1998 \\
\hline & $\begin{array}{l}\text { Rabbit and mouse model of } \\
\text { corneal NV }\end{array}$ & $\begin{array}{l}\text { Effects of curcuminoids on } \\
\text { FGF-2-induced corneal NV }\end{array}$ & $\begin{array}{l}\text { Localized and systemic delivery of curcuminoids } \\
\text { inhibited the angioproliferative response to FGF-2 } \\
\text { stimulation in rabbit and mouse corneas. }\end{array}$ & Mohan et al., 2000 \\
\hline & Rabbit model of corneal NV & $\begin{array}{l}\text { Effect of curcumin on } \\
\text { suturing-induced corneal NV }\end{array}$ & $\begin{array}{l}\text { Topically curcumin inhibited suturing-induced corneal } \\
\text { NV and VEGF mRNA upregulation. }\end{array}$ & Kim et al., 2010 \\
\hline & $\begin{array}{l}\text { Aortic ring assay, rat model of } \\
\text { corneal NV }\end{array}$ & $\begin{array}{l}\text { Effect of curcumin NPs on silver } \\
\text { nitrate-induced corneal NV }\end{array}$ & $\begin{array}{l}\text { Topically curcumin NPs suppressed the expression of } \\
\text { VEGF, inflammatory cytokines, and MMP. It prevented } \\
\text { corneal NV by suppressing the NF-кB pathway. }\end{array}$ & Pradhan et al., 2015 \\
\hline & $\begin{array}{l}\text { STZ-induced diabetic mice } \\
\text { model with corneal epithelium } \\
\text { abrasion }\end{array}$ & $\begin{array}{l}\text { Effect of nanomicelle curcumin } \\
\text { on corneal epithelial wound } \\
\text { healing }\end{array}$ & $\begin{array}{l}\text { Intranasal nanomicelle curcumin effectively promoted } \\
\text { corneal epithelial/nerve wound healing in diabetic mice. }\end{array}$ & Guo et al., 2016 \\
\hline \multirow[t]{2}{*}{ Conjunctiva } & Patients & $\begin{array}{l}\text { Effect of Curcuma-Longa on } \\
\text { bacterial conjunctivitis }\end{array}$ & $\begin{array}{l}\text { Curcuma-Longa had an active role on E. Coli, } \\
\text { St. Aureus, Klebshella and pseudomonas organisms. }\end{array}$ & $\begin{array}{l}\text { Srinivas and } \\
\text { Prabhakaran, } 1989\end{array}$ \\
\hline & Mice model of AC & $\begin{array}{l}\text { Effect of curcumin on } \\
\text { ovalbumin-induced AC }\end{array}$ & $\begin{array}{l}\text { Curcumin inhibited the ovalbumin-induced iNOS } \\
\text { activation, IL-4 and IL-5 production in the mice } \\
\text { conjunctiva. }\end{array}$ & Chung et al., 2012 \\
\hline $\begin{array}{l}\text { Conjunctiva/ } \\
\text { Cornea }\end{array}$ & $\begin{array}{l}\text { Cultured human pterygium } \\
\text { fibroblasts }\end{array}$ & $\begin{array}{l}\text { Effect of curcumin on pterygium } \\
\text { fibroblasts }\end{array}$ & $\begin{array}{l}\text { Curcumin stopped the proliferation and caused the cell } \\
\text { death of human pterygium fibroblasts. }\end{array}$ & Zhang et al., 2007 \\
\hline \multirow[t]{4}{*}{ Uvea } & Patients & $\begin{array}{l}\text { Effect of curcumin on chronic } \\
\text { anterior uveitis }\end{array}$ & $\begin{array}{l}\text { Orally curcumin improved patients' chronic anterior } \\
\text { uveitis with improved vision, decreased aqueous flare, } \\
\text { and keratic precipitates. }\end{array}$ & Lal et al., 1999 \\
\hline & Patients & $\begin{array}{l}\text { Effect of } \\
\text { curcumin-phosphatidylcholine } \\
\text { complex on recurrent anterior } \\
\text { uveitis }\end{array}$ & $\begin{array}{l}\text { Orally curcumin-phosphatidylcholine complex improved } \\
\text { recurrent anterior uveitis in more than } 80 \% \text { of patients. }\end{array}$ & Allegri et al., 2010 \\
\hline & $\begin{array}{l}\text { E. coli } \\
\text { lipopolysaccharide-induced rat } \\
\text { uveitis }\end{array}$ & $\begin{array}{l}\text { Effect of Curcuma-longa on } \\
\text { endotoxin-induced uveal } \\
\text { inflammation }\end{array}$ & $\begin{array}{l}\text { Topical Curcuma-longa suppressed E. coli } \\
\text { lipopolysaccharide-induced uveitis in rats by reducing } \\
\text { TNF- } \alpha \text { activity. }\end{array}$ & Agarwal et al., 2013 \\
\hline & $\begin{array}{l}\text { E. coli } \\
\text { lipopolysaccharide-induced rat } \\
\text { uveitis }\end{array}$ & $\begin{array}{l}\text { Effect of topical } \\
\text { Curcuma-longa on } \\
\text { endotoxin-induced uveal } \\
\text { inflammation }\end{array}$ & $\begin{array}{l}\text { Topical Curcuma-longa showed anti-inflammatory } \\
\text { activity against endotoxin-induced uveitis in rabbits. }\end{array}$ & Gupta et al., 2008 \\
\hline Lens & see Table 1 & & & \\
\hline \multirow[t]{3}{*}{$\begin{array}{l}\text { Neuronal } \\
\text { /Glial }\end{array}$} & $\begin{array}{l}\text { NMDA treated cultured retinal } \\
\text { neuronal/glial cells }\end{array}$ & $\begin{array}{l}\text { Effect of curcumin on retinal } \\
\text { neuronal/glial cultures }\end{array}$ & $\begin{array}{l}\text { Curcumin attenuates NMDA-induced apoptosis in } \\
\text { retinal neuronal/glial cultures by inhibiting the } \\
\text { phosphorylation of the NR1 subunit of the NMDA } \\
\text { receptor, showing curcumin possed neuroprotective } \\
\text { effects by inhibiting NMDA mediated excitotoxicity. }\end{array}$ & Matteucci et al., 2005 \\
\hline & $\begin{array}{l}\text { Cultured BV-2 microglia cell } \\
\text { line, rat model of chronic high } \\
\text { intraocular pressure }\end{array}$ & $\begin{array}{l}\text { Neuroprotective effect of } \\
\text { curcumin on } \mathrm{H}_{2} \mathrm{O}_{2} \text { treated } \\
\mathrm{BV}-2 \text { microglia cell line and } \\
\text { microglia under chronic high } \\
\text { intraocular pressure }\end{array}$ & $\begin{array}{l}\text { Curcumin increased the cell viability of } \mathrm{H}_{2} \mathrm{O}_{2} \text {-treated } \\
\text { BV-2 microglia and decreased the intracellular ROS and } \\
\text { apoptosis. It protected microglia from death in chronic } \\
\text { high intraocular pressure rat model. In both models, } \\
\text { caspase 3, cytochrome c, and BAX were } \\
\text { downregulated and BCL2 was upregulated in the } \\
\text { curcumin-treated group. }\end{array}$ & Yue et al., 2014 \\
\hline & $\begin{array}{l}\text { Staurosporine treated } \\
\text { transformed mouse RGC-5 and } \\
\text { mice }\end{array}$ & $\begin{array}{l}\text { Effect of curcumin on death of } \\
\text { retinal ganglion cells }\end{array}$ & $\begin{array}{l}\text { Curcumin attenuated RGC and amacrine cell loss, by } \\
\text { restoring NF-кB expression. }\end{array}$ & Burugula et al., 2011 \\
\hline
\end{tabular}

(Continued) 
TABLE 2 | Continued

\begin{tabular}{|c|c|c|c|c|}
\hline Region & Models & Oberservation & Results & Reference \\
\hline & $\begin{array}{l}\text { Rat model of acute retinal I/R } \\
\text { injury }\end{array}$ & $\begin{array}{l}\text { Effect of curcumin on retinal I/R } \\
\text { injury }\end{array}$ & $\begin{array}{l}\text { Curcumin could reverse the decrease of mfn2 and the } \\
\text { increase of Nrf2 in the retinal l/R-induced glaucoma } \\
\text { model. It protected retinal neurons and microvessels } \\
\text { against I/R injury, may occur through its inhibitory } \\
\text { effects on injury-induced activation of NF-кB and } \\
\text { STAT3, and over-expression of MCP-1. }\end{array}$ & Wang et al., 2011 \\
\hline
\end{tabular}

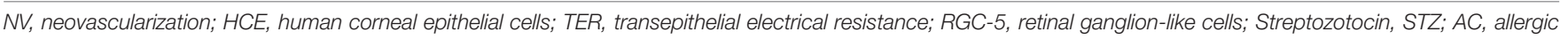
conjunctivitis.

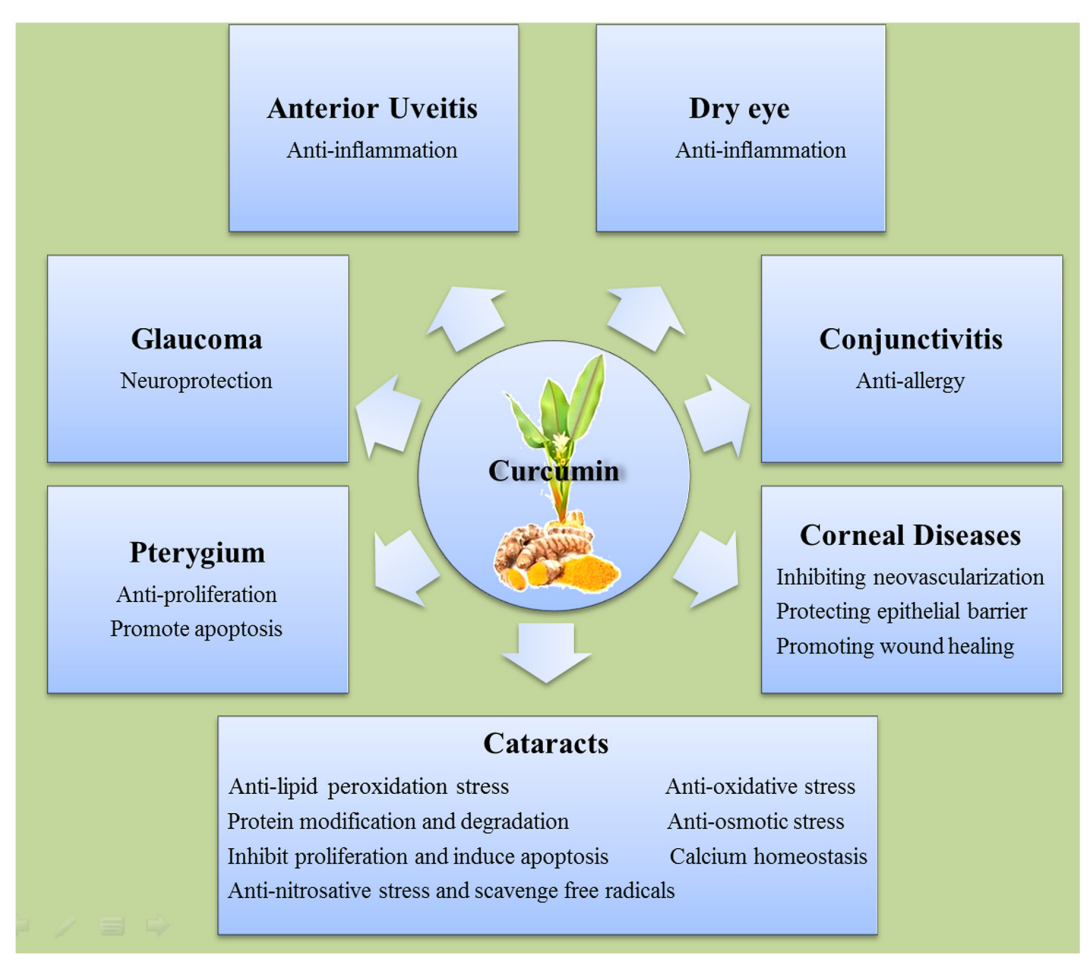

FIGURE 2 | The mechanisms of the beneficial effects of curcumin on different anterior segment eye diseases.

could inhibit proliferation of human lens epithelial B3 (HLEB3) cells cultured in vitro ( $\mathrm{Hu}$ et al., 2012). It may also induce irreversible apoptosis in bovine lens epithelial cells cultured in vitro, through attenuating mitochondrial transmembrane potential in cytoplasm and decreasing DNA content in nucleus (Huang et al., 2006). Further in vivo experiments are needed to validate curcumin's effects on proliferation and apoptosis in lens epithelial cells.

Thus, as a viable food-based pharmacologic drug, numerous studies (summarized in Table 1) have demonstrated that curcumin may protect again cataracts and may serve as an effective and low toxic medication for the prevention and treatment of cataract.

\section{Glaucoma}

As a chronic, progressive, irreversible optic nerve neuropathy, glaucoma has already affected more than 60 million people worldwide by 2010 (Quigley and Broman, 2006), and the number continues to grow. It is characterized by persistent loss of retinal ganglion cells, thinning of the retinal nerve fiber layer, and progressive loss of the vision field (Quigley, 1993). However, the exact underlying pathological mechanisms remain unclear. Elevated intraocular pressure is the most critical risk for glaucoma, and it was reported to cause damage to the optic nerve through retinal ganglion cell apoptosis (Ritch, 2007). The most important clinical treatment is lowering the intraocular pressure, using eye drops, oral medications or surgeries. But lowering the intraocular pressure only slows down glaucoma progress, rather than preventing it. In some cases, even when eye pressure has been lowered to normal levels, glaucoma progresses anyway. Thus, neuroprotective agents are desired to prevent or limit or even recover the damage to the optic nerve.

Curcumin was reported to possess neuroprotective properties, which may be effective in the prevention and treatment of glaucoma. In a chronic high intraocular pressure in vivo 
rat model, pretreatment of curcumin was correlated with significantly increased cell viability of BV-2 microglia and the increase presence of ROS and a dramatic decrease in apoptosis of BV-2 microglia, which indicate that curcumin may offer neuroprotective effects by inhibiting oxidative damage to microglia (Yue et al., 2014). Curcumin was also reported to protect against the loss of retinal ganglion cells in the same chronic high intraocular pressure model (Yue et al., 2014). In another research, staurosporine (SS)induced ganglion cell death was attenuated by low dosages of curcumin $(<50 \mathrm{M})$ both in vitro and in vivo (Burugula et al., 2011). Acute retinal ischemia induced by high intraocular pressure followed by reperfusion $(\mathrm{I} / \mathrm{R})$ is an animal model for open-angle glaucoma. Dietary curcumin was reported to have a neuroprotective effect for retinal I/R injury. One important pathogenic cause for glaucoma is mitochondrial dysfunction. Mitofusin $2(\mathrm{mfn} 2)$, a mitochondrial fusion protein, is decreased after retinal $\mathrm{I} / \mathrm{R}$ injury. Nuclear factor erythroid 2-related factor 2 (Nrf2) has a protective effect against oxidative stress, and is increased after the retinal $I / R$ injury. Pretreat of curcumin may reverse the decrease of $\mathrm{mfn} 2$ and the increase of nuclear factor erythroid 2-related factor 2 (Nrf2) in the retinal I/R-induced open-angle glaucoma model in vivo, indicating that curcumin could maintain the normal mitochondrial function and alleviate the retinal $\mathrm{I} / \mathrm{R}$ injury by regulating the antioxidant system (Wang et al., 2011). Another important pathogenic cause for glaucoma is excitotoxicity (Wax and Tezel, 2002). Pretreat of curcumin significantly attenuates $N$-methyl-D-aspartate (NMDA)-induced apoptosis in retinal neuronal/glial cultures in vitro by inhibiting the NR1 subunit of the NMDA receptor (NMDAR) phosphorylation and NMDAR-mediated $\mathrm{Ca}^{2+}$ increase, demonstrating that curcumin possesses neuroprotective effects (Matteucci et al., 2005). Thus, curcumin could be a potential treatment strategy for glaucoma.

\section{REFERENCES}

Abdelkader, H., Patel, D. V., McGhee, C., and Alany, R. G. (2011). New therapeutic approaches in the treatment of diabetic keratopathy: a review. Clin. Exp. Ophthalmol. 39, 259-270. doi: 10.1111/j.1442-9071.2010.02435.x

Agarwal, R., Gupta, S. K., Agarwal, P., and Srivastava, S. (2013). Topically applied standardized aqueous extract of Curcuma longa Linn. suppresses endotoxininduced uveal inflammation in rats. Indian J. Exp. Biol. 51, 797-803.

Aggarwal, B. B., and Sung, B. (2009). Pharmacological basis for the role of curcumin in chronic diseases: an age-old spice with modern targets. Trends Pharmacol. Sci. 30, 85-94. doi: 10.1016/j.tips.2008.11.002

Allegri, P., Mastromarino, A., and Neri, P. (2010). Management of chronic anterior uveitis relapses: efficacy of oral phospholipidic curcumin treatment. Long-term follow-up. Clin. Ophthalmol. 4, 1201-1206. doi: 10.2147/OPTH.S13271

Ammon, H. P., Anazodo, M. I., Safayhi, H., Dhawan, B. N., and Srimal, R. C. (1992). Curcumin: a potent inhibitor of leukotriene B4 formation in rat peritoneal polymorphonuclear neutrophils (PMNL). Planta Med. 58:226. doi: 10.1055/s2006-961438

Anand, P., Kunnumakkara, A. B., Newman, R. A., and Aggarwal, B. B. (2007). Bioavailability of curcumin: problems and promises. Mol. Pharm. 4, 807-818. doi: $10.1021 / \mathrm{mp} 700113 \mathrm{r}$

Anand, P., Sundaram, C., Jhurani, S., Kunnumakkara, A. B., and Aggarwal, B. B. (2008). Curcumin and cancer: an "old-age" disease with an "age-old" solution. Cancer Lett. 267, 133-164. doi: 10.1016/j.canlet.2008.03.025

\section{CONCLUSIONS AND OUTLOOK}

Since ancient time, curcumin has been used in cooking and traditional medicine in both China and India. Modern science has illuminated many molecular basics for which the pharmaceutical use of curcumin may aid with human ailments. The selected observational studies on the relationship between curcumin and anterior segment eye diseases were summarized in Table 2. The mechanisms underlying the beneficial effects of curcumin on anterior segment eye diseases are summarized in Figure 2. In vitro, in vivo, and human clinical studies have suggested that curcumin has a diverse range of molecular targets, supporting the concept that it interacts with multiple cellular signaling pathways and modulates numerous molecular targets. Curcumin's harmless nature, low cost, and multiple targeting potential make it a promising agent for the prevention and treatment of various eye diseases. Accumulating evidence has demonstrated its potential therapeutic value. Nevertheless, more randomized clinical trials are needed in order to solidify our understanding of its therapeutic potential.

\section{AUTHOR CONTRIBUTIONS}

The topic was conceptualized by CL. CL, XL, DZ, and TX contributed to the literature database search, and writing of the manuscript. JH and NM contributed to vital revising. WZ and TM contribute to English Polishing.

\section{ACKNOWLEDGMENT}

The study was funded by Development and Reform Commission of Jilin Province 2015Y031-1, and the First Hospital of Jilin University grant JDYY72016055.

Arbiser, J. L., Klauber, N., Rohan, R., van Leeuwen, R., Huang, M. T., Fisher, C., et al. (1998). Curcumin is an in vivo inhibitor of angiogenesis. Mol. Med. 4, 376-383.

Awasthi, S., Srivatava, S. K., Piper, J. T., Singhal, S. S., Chaubey, M., and Awasthi, Y. C. (1996). Curcumin protects against 4-hydroxy-2-trans-nonenal-induced cataract formation in rat lenses. Am. J. Clin. Nutr. 64, 761-766.

Bimonte, S., Barbieri, A., Palma, G., Rea, D., Luciano, A., D’Aiuto, M., et al. (2015). Dissecting the role of curcumin in tumour growth and angiogenesis in mouse model of human breast cancer. Biomed. Res. Int. 2015:878134. doi: $10.1155 / 2015 / 878134$

Biswas, N. R., Gupta, S. K., Das, G. K., Kumar, N., Mongre, P. K., Haldar, D., et al. (2001). Evaluation of Ophthacare eye drops-a herbal formulation in the management of various ophthalmic disorders. Phytother. Res. 15, 618-620.

Brouet, I., and Ohshima, H. (1995). Curcumin, an anti-tumour promoter and antiinflammatory agent, inhibits induction of nitric oxide synthase in activated macrophages. Biochem. Biophys. Res. Commun. 206, 533-540.

Burugula, B., Ganesh, B. S., and Chintala, S. K. (2011). Curcumin attenuates staurosporine-mediated death of retinal ganglion cells. Invest. Ophthalmol. Vis. Sci. 52, 4263-4273. doi: 10.1167/iovs.10-7103

Chang, J. H., Gabison, E. E., Kato, T., and Azar, D. T. (2001). Corneal neovascularization. Curr. Opin. Ophthalmol. 12, 242-249.

Chang, J. H., and Wakefield, D. (2002). Uveitis: a global perspective. Ocul. Immunol. Inflamm. 10, 263-279. 
Chen, A., Xu, J., and Johnson, A. C. (2006). Curcumin inhibits human colon cancer cell growth by suppressing gene expression of epidermal growth factor receptor through reducing the activity of the transcription factor Egr-1. Oncogene 25, 278-287. doi: 10.1038/sj.onc.1209019

Chen, M., Hu, D. N., Pan, Z., Lu, C. W., Xue, C. Y., and Aass, I. (2010). Curcumin protects against hyperosmoticity-induced IL-1beta elevation in human corneal epithelial cell via MAPK pathways. Exp. Eye Res. 90, 437-443. doi: 10.1016/j. exer.2009.12.004

Chhunchha, B., Fatma, N., Bhargavan, B., Kubo, E., Kumar, A., and Singh, D. P. (2011). Specificity protein, Sp1-mediated increased expression of Prdx6 as a curcumin-induced antioxidant defense in lens epithelial cells against oxidative stress. Cell Death Dis. 2:e234. doi: 10.1038/cddis.2011.121

Chotikavanich, S., de Paiva, C. S., Li de, Q., Chen, J. J., Bian, F., Farley, W. J., et al. (2009). Production and activity of matrix metalloproteinase-9 on the ocular surface increase in dysfunctional tear syndrome. Invest. Ophthalmol. Vis. Sci. 50, 3203-3209. doi: 10.1167/iovs.08-2476

Chung, S. H., Choi, S. H., Choi, J. A., Chuck, R. S., and Joo, C. K. (2012). Curcumin suppresses ovalbumin-induced allergic conjunctivitis. Mol. Vis. 18, 1966-1972.

Creighton, M. O., Ross, W. M., Stewart-DeHaan, P. J., Sanwal, M., and Trevithick, J. R. (1985). Modelling cortical cataractogenesis VII: effects of vitamin E treatment on galactose-induced cataracts. Exp. Eye Res. 40, 213-222.

Das, M., and Sahoo, S. K. (2012). Folate decorated dual drug loaded nanoparticle: role of curcumin in enhancing therapeutic potential of nutlin-3a by reversing multidrug resistance. PLoS ONE 7:e32920. doi: 10.1371/journal.pone.0032920

Dikshit, M., Rastogi, L., Shukla, R., and Srimal, R. C. (1995). Prevention of ischaemia-induced biochemical changes by curcumin \& quinidine in the cat heart. Indian J. Med. Res. 101, 31-35.

Duan, Y., Cai, X., Du, H., and Zhai, G. (2015). Novel in situ gel systems based on P123/TPGS mixed micelles and gellan gum for ophthalmic delivery of curcumin. Colloids Surf. B. Biointerfaces 128, 322-330. doi: 10.1016/j.colsurfb. 2015.02.007

Flynn, D. L., Rafferty, M. F., and Boctor, A. M. (1986). Inhibition of 5-hydroxyeicosatetraenoic acid (5-HETE) formation in intact human neutrophils by naturally-occurring diarylheptanoids: inhibitory activities of curcuminoids and yakuchinones. Prostaglandins Leukot. Med. 22, 357-360.

Foster, A., and Resnikoff, S. (2005). The impact of Vision 2020 on global blindness. Eye (Lond). 19, 1133-1135. doi: 10.1038/sj.eye.6701973

Fu, S., Dean, R., Southan, M., and Truscott, R. (1998). The hydroxyl radical in lens nuclear cataractogenesis. J. Biol. Chem. 273, 28603-28609.

Gao, Y., Zhang, Y., Ru, Y. S., Wang, X. W., Yang, J. Z., Li, C. H., et al. (2015). Ocular surface changes in type II diabetic patients with proliferative diabetic retinopathy. Int. J. Ophthalmol. 8, 358-364. doi: 10.3980/j.issn.2222-3959.2015. 02.26

Graham, A., Hogg, N., Kalyanaraman, B., O’Leary, V., Darley-Usmar, V., and Moncada, S. (1993). Peroxynitrite modification of low-density lipoprotein leads to recognition by the macrophage scavenger receptor. FEBS Lett. 330, 181-185.

Grama, C. N., Suryanarayana, P., Patil, M. A., Raghu, G., Balakrishna, N., Kumar, M. N., et al. (2013). Efficacy of biodegradable curcumin nanoparticles in delaying cataract in diabetic rat model. PLOS ONE 8:e78217. doi: 10.1371/ journal.pone.0078217

Gregus, Z., Fekete, T., Halaszi, E., and Klaassen, C. D. (1996). Lipoic acid impairs glycine conjugation of benzoic acid and renal excretion of benzoylglycine. Drug Metab. Dispos. 24, 682-688.

Guidera, A. C., Luchs, J. I., and Udell, I. J. (2001). Keratitis, ulceration, and perforation associated with topical nonsteroidal anti-inflammatory drugs. Ophthalmology 108, 936-944.

Guo, C., Li, M., Qi, X., Lin, G., Cui, F., Li, F., et al. (2016). Intranasal delivery of nanomicelle curcumin promotes corneal epithelial wound healing in streptozotocin-induced diabetic mice. Sci. Rep. 6:29753. doi: 10.1038/srep 29753

Gupta, S. K., Agarwal, R., Srivastava, S., Agarwal, P., Agrawal, S. S., Saxena, R., et al. (2008). The anti-inflammatory effects of Curcuma longa and Berberis aristata in endotoxin-induced uveitis in rabbits. Invest. Ophthalmol. Vis. Sci. 49, 4036-4040. doi: 10.1167/iovs.07-1186

Hightower, K. R., and McCready, J. P. (1989). Effects of selenium on ion homeostasis and transparency in cultured lenses. Invest. Ophthalmol. Vis. Sci. $30,171-175$.
Hu, Y. H., Huang, X. R., Qi, M. X., and Hou, B. Y. (2012). Curcumin inhibits proliferation of human lens epithelial cells: a proteomic analysis. J. Zhejiang Univ. Sci. B 13, 402-407. doi: 10.1631/jzus.B1100278

Huang, X. R., Qi, M. X., and Kang, K. R. (2006). [Apoptosis of lens epithelial cell induced by curcumin and its mechanism]. Zhonghua Yan Ke Za Zhi 42, 649-653.

Huynh, T. P., Mann, S. N., and Mandal, N. A. (2013). Botanical compounds: effects on major eye diseases. Evid. Based Complement. Alternat. Med. 2013:549174. doi: $10.1155 / 2013 / 549174$

Ito, Y., Nabekura, T., Takeda, M., Nakao, M., Terao, M., Hori, R., et al. (2001). Nitric oxide participates in cataract development in selenite-treated rats. Curr. Eye Res. 22, 215-220.

Joe, B., and Lokesh, B. R. (1994). Role of capsaicin, curcumin and dietary n-3 fatty acids in lowering the generation of reactive oxygen species in rat peritoneal macrophages. Biochim. Biophys. Acta 1224, 255-263.

Joseph, M., Trinh, H. M., Cholkar, K., Pal, D., and Mitra, A. K. (2016). Recent perspectives on the delivery of biologics to back of the eye. Expert. Opin. Drug Deliv. 140, 1-15. doi: 10.1080/17425247.2016.1227783

Kim, J. S., Choi, J. S., and Chung, S. K. (2010). The effect of curcumin on corneal neovascularization in rabbit eyes. Curr. Eye Res. 35, 274-280. doi: 10.3109/ 02713680903528345

Kim, S. W., Ha, B. J., Kim, E. K., Tchah, H., and Kim, T. I. (2008). The effect of topical bevacizumab on corneal neovascularization. Ophthalmology 115, e33-e38. doi: 10.1016/j.ophtha.2008.02.013

Kimura, K. (2010). [Molecular mechanism of the disruption of barrier function in cultured human corneal epithelial cells induced by tumor necrosis factor-alpha, a proinflammatory cytokine]. Nippon Ganka Gakkai Zasshi 114, 935-943.

Kimura, K., Teranishi, S., Fukuda, K., Kawamoto, K., and Nishida, T. (2008). Delayed disruption of barrier function in cultured human corneal epithelial cells induced by tumor necrosis factor-alpha in a manner dependent on NF-kappaB. Invest. Ophthalmol. Vis. Sci. 49, 565-571. doi: 10.1167/iovs. 07-0419

Kimura, K., Teranishi, S., and Nishida, T. (2009). Interleukin-1 $\beta$-induced disruption of barrier function in cultured human corneal epithelial cells. Invest. Ophthalmol. Vis. Sci. 50, 597-603. doi: 10.1167/iovs.08-2606

Koenig, Y., Bock, F., Kruse, F. E., Stock, K., and Cursiefen, C. (2012). Angioregressive pretreatment of mature corneal blood vessels before keratoplasty: fine-needle vessel coagulation combined with anti-VEGFs. Cornea 31, 887-892. doi: 10.1097/ICO.0b013e31823f8f7a

Krishnaraju, A. V., Sundararaju, D., Sengupta, K., Venkateswarlu, S., and Trimurtulu, G. (2009). Safety and toxicological evaluation of demethylatedcurcuminoids; a novel standardized curcumin product. Toxicol. Mech. Methods 19, 447-460. doi: 10.1080/15376510903200766

Kumar, P. A., Haseeb, A., Suryanarayana, P., Ehtesham, N. Z., and Reddy, G. B. (2005a). Elevated expression of alphaA- and alphaB-crystallins in streptozotocin-induced diabetic rat. Arch. Biochem. Biophys. 444, 77-83. doi: 10.1016/j.abb.2005.09.021

Kumar, P. A., Suryanarayana, P., Reddy, P. Y., and Reddy, G. B. (2005b). Modulation of alpha-crystallin chaperone activity in diabetic rat lens by curcumin. Mol. Vis. 11, 561-568.

Kupfer, C. (1985). Bowman lecture. The conquest of cataract: a global challenge. Trans. Ophthalmol. Soc. U K. 104(Pt 1), 1-10.

Lal, B., Kapoor, A. K., Asthana, O. P., Agrawal, P. K., Prasad, R., Kumar, P., et al. (1999). Efficacy of curcumin in the management of chronic anterior uveitis. Phytother. Res. 13, 318-322.

Lemp, M. A. (2007). The definition and classification of dry eye disease: report of the definition and classification subcommittee of the international dry eye workshop (2007). Ocul. Surf. 5, 75-92.

Li, D. Q., Luo, L., Chen, Z., Kim, H. S., Song, X. J., and Pflugfelder, S. C. (2006). JNK and ERK MAP kinases mediate induction of IL-1beta, TNF-alpha and IL-8 following hyperosmolar stress in human limbal epithelial cells. Exp. Eye Res. 82, 588-596. doi: 10.1016/j.exer.2005.08.019

Liu, R., Liu, Z., Zhang, C., and Zhang, B. (2011). Gelucire44/14 as a novel absorption enhancer for drugs with different hydrophilicities: in vitro and in vivo improvement on transcorneal permeation. J. Pharm. Sci. 100, 31863195. doi: 10.1002/jps.22540

Liu, R., Sun, L., Fang, S., Wang, S., Chen, J., Xiao, X., et al. (2016). Thermosensitive in situ nanogel as ophthalmic delivery system of curcumin: development, 
characterization, in vitro permeation and in vivo pharmacokinetic studies. Pharm. Dev. Technol. 21, 576-582. doi: 10.3109/10837450.2015.1026607

Lou, J., Hu, W., Tian, R., Zhang, H., Jia, Y., Zhang, J., et al. (2014). Optimization and evaluation of a thermoresponsive ophthalmic in situ gel containing curcuminloaded albumin nanoparticles. Int. J. Nanomedicine 9, 2517-2525. doi: 10.2147/ IJN.S60270

Lu, C., Song, E., Hu, D. N., Chen, M., Xue, C., Rosen, R., et al. (2010). Curcumin induces cell death in human uveal melanoma cells through mitochondrial pathway. Curr. Eye Res. 35, 352-360. doi: 10.3109/02713680903521944

Maheshwari, R. K., Singh, A. K., Gaddipati, J., and Srimal, R. C. (2006). Multiple biological activities of curcumin: a short review. Life Sci. 78, 2081-2087. doi: 10.1016/j.lfs.2005.12.007

Manikandan, R., Beulaja, M., Thiagarajan, R., and Arumugam, M. (2011). Effect of curcumin on the modulation of alphaA- and alphaB-crystallin and heat shock protein 70 in selenium-induced cataractogenesis in Wistar rat pups. Mol. Vis. $17,388-394$.

Manikandan, R., Thiagarajan, R., Beulaja, S., Chindhu, S., Mariammal, K., Sudhandiran, G., et al. (2009). Anti-cataractogenic effect of curcumin and aminoguanidine against selenium-induced oxidative stress in the eye lens of Wistar rat pups: an in vitro study using isolated lens. Chem. Biol. Interact. 181, 202-209. doi: 10.1016/j.cbi.2009.05.011

Manikandan, R., Thiagarajan, R., Beulaja, S., Sudhandiran, G., and Arumugam, M. (2010a). Curcumin prevents free radical-mediated cataractogenesis through modulations in lens calcium. Free Radic. Biol. Med. 48, 483-492. doi: 10.1016/j. freeradbiomed.2009.11.011

Manikandan, R., Thiagarajan, R., Beulaja, S., Sudhandiran, G., and Arumugam, M. (2010b). Effect of curcumin on selenite-induced cataractogenesis in Wistar rat pups. Curr. Eye Res. 35, 122-129. doi: 10.3109/02713680903 447884

Marczylo, T. H., Verschoyle, R. D., Cooke, D. N., Morazzoni, P., Steward, W. P., and Gescher, A. J. (2007). Comparison of systemic availability of curcumin with that of curcumin formulated with phosphatidylcholine. Cancer Chemother. Pharmacol. 60, 171-177. doi: 10.1007/s00280-006-0355-x

Matteucci, A., Frank, C., Domenici, M. R., Balduzzi, M., Paradisi, S., CarnovaleScalzo, G., et al. (2005). Curcumin treatment protects rat retinal neurons against excitotoxicity: effect on N-methyl-D: -aspartate-induced intracellular $\mathrm{Ca}(2+)$ increase. Exp. Brain Res. 167, 641-648.

Merida, S., Palacios, E., Navea, A., and Bosch-Morell, F. (2015). New Immunosuppressive therapies in uveitis treatment. Int. J. Mol. Sci. 16, 1877818795. doi: 10.3390/ijms160818778

Mohan, R., Sivak, J., Ashton, P., Russo, L. A., Pham, B. Q., Kasahara, N., et al. (2000). Curcuminoids inhibit the angiogenic response stimulated by fibroblast growth factor-2, including expression of matrix metalloproteinase gelatinase $\mathrm{B}$. J. Biol. Chem. 275, 10405-10412.

Murugan, P., and Pari, L. (2006). Antioxidant effect of tetrahydrocurcumin in streptozotocin-nicotinamide induced diabetic rats. Life Sci. 79, 1720-1728. doi: 10.1016/j.lfs.2006.06.001

Niederkorn, J. Y., Stern, M. E., Pflugfelder, S. C., De Paiva, C. S., Corrales, R. M., Gao, J., et al. (2006). Desiccating stress induces T cell-mediated Sjogren's Syndrome-like lacrimal keratoconjunctivitis. J. Immunol. 176, 3950-3957.

Oh, J. Y., Kim, M. K., and Wee, W. R. (2009). Subconjunctival and intracorneal bevacizumab injection for corneal neovascularization in lipid keratopathy. Cornea 28, 1070-1073. doi: 10.1097/ICO.0b013e31819839f9

Ornek, K., Karel, F., and Buyukbingol, Z. (2003). May nitric oxide molecule have a role in the pathogenesis of human cataract? Exp. Eye Res. 76, 23-27.

Padmaja, S., and Raju, T. N. (2004). Antioxidant effect of curcumin in selenium induced cataract of Wistar rats. Indian J. Exp. Biol. 42, 601-603.

Pandya, U., Saini, M. K., Jin, G. F., Awasthi, S., Godley, B. F., and Awasthi, Y. C. (2000). Dietary curcumin prevents ocular toxicity of naphthalene in rats. Toxicol. Lett. 115, 195-204.

Pradhan, N., Guha, R., Chowdhury, S., Nandi, S., Konar, A., and Hazra, S. (2015). Curcumin nanoparticles inhibit corneal neovascularization. J. Mol. Med (Berl). 93, 1095-1106. doi: 10.1007/s00109-015-1277-z

Prasad, S., Gupta, S. C., Tyagi, A. K., and Aggarwal, B. B. (2014). Curcumin, a component of golden spice: from bedside to bench and back. Biotechnol. Adv. 32, 1053-1064. doi: 10.1016/j.biotechadv.2014.04.004

Quigley, H. A. (1993). Open-angle glaucoma. N. Engl. J. Med. 328, 1097-1106. doi: 10.1056/NEJM199304153281507
Quigley, H. A., and Broman, A. T. (2006). The number of people with glaucoma worldwide in 2010 and 2020. Br. J. Ophthalmol. 90, 262-267. doi: 10.1136/bjo. 2005.081224

Radha, A., Devi Rukhmini, S., Sasikala, V., Sakunthala, P. R., Sreedharan, B., Velayudhan, M. P., et al. (2012). Bioactive derivatives of curcumin attenuate cataract formation in vitro. Chem. Biol. Drug Des. 80, 887-892. doi: 10.1111/ cbdd. 12021

Rahman, I., Biswas, S. K., and Kirkham, P. A. (2006). Regulation of inflammation and redox signaling by dietary polyphenols. Biochem. Pharmacol. 72, 14391452. doi: 10.1016/j.bcp.2006.07.004

Rajakumar, D. V., and Rao, M. N. (1994). Antioxidant properties of dehydrozingerone and curcumin in rat brain homogenates. Mol. Cell Biochem. 140, 73-79.

Raju, T. N., Kumar, C. S., Kanth, V. R., Ramana, B. V., Reddy, P. U., Suryanarayana, P., et al. (2006). Cumulative antioxidant defense against oxidative challenge in galactose-induced cataractogenesis in Wistar rats. Indian J. Exp. Biol. 44, 733-739.

Resnikoff, S., Pascolini, D., Mariotti, S. P., and Pokharel, G. P. (2008). Global magnitude of visual impairment caused by uncorrected refractive errors in 2004. Bull. World Health Organ. 86, 63-70.

Ritch, R. (2007). Natural compounds: evidence for a protective role in eye disease. Can. J. Ophthalmol. 42, 425-438.

Sarchahi, A. A., Maimandi, A., Tafti, A. K., and Amani, M. (2008). Effects of acetylcysteine and dexamethasone on experimental corneal wounds in rabbits. Ophthalmic. Res. 40, 41-48. doi: 10.1159/000111158

Sener, S., Braun, J. P., Rico, A. G., Benard, P., and Burgat-Sacaze, V. (1979). Urine gamma-glutamyl transferase in rat kidney toxicology: nephropathy by repeated injections of mercuric chloride. Effects of sodium selenite. Toxicology 12, 299-305.

Shah, S. I., Shah, S. A., and Rai, P. (2016). Factors associated with pterygium based on history and clinical examination of patients in Pakistan. J. Curr. Ophthalmol. 28, 91-92. doi: 10.1016/j.joco.2016.03.005

Shakiba, Y., Mansouri, K., Arshadi, D., and Rezaei, N. (2009). Corneal neovascularization: molecular events and therapeutic options. Recent Pat. Inflamm. Allergy Drug Discov. 3, 221-231.

Shearer, T. R., and David, L. L. (1982). Role of calcium in selenium cataract. Curr. Eye Res. 2, 777-784.

Shoji, M., Sun, A., Kisiel, W., Lu, Y. J., Shim, H., McCarey, B. E., et al. (2008). Targeting tissue factor-expressing tumor angiogenesis and tumors with EF24 conjugated to factor VIIa. J. Drug Target. 16, 185-197. doi: 10.1080/ 10611860801890093

Solomon, A., Dursun, D., Liu, Z., Xie, Y., Macri, A., and Pflugfelder, S. C. (2001). Pro- and anti-inflammatory forms of interleukin-1 in the tear fluid and conjunctiva of patients with dry-eye disease. Invest. Ophthalmol. Vis. Sci. 42, 2283-2292.

Spector, A. (1995). Oxidative stress-induced cataract: mechanism of action. FASEB J. 9, 1173-1182.

Srinivas, C., and Prabhakaran, K. V. (1989). Haridra (curcuma longa) and its effect on abhisayanda (conjunctivitis). Anc. Sci. Life 8, 279-282.

Srivastava, R., and Srimal, R. C. (1985). Modification of certain inflammationinduced biochemical changes by curcumin. Indian J. Med. Res. 81, 215-223.

Steigerwalt, R., Nebbioso, M., Appendino, G., Belcaro, G., Ciammaichella, G., Cornelli, U., et al. (2012). Meriva(R), a lecithinized curcumin delivery system, in diabetic microangiopathy and retinopathy. Panminerva Med. 54, $11-16$.

Strimpakos, A. S., and Sharma, R. A. (2008). Curcumin: preventive and therapeutic properties in laboratory studies and clinical trials. Antioxid. Redox Signal. 10, 511-545. doi: 10.1089/ars.2007.1769

Suryanarayana, P., Krishnaswamy, K., and Reddy, G. B. (2003). Effect of curcumin on galactose-induced cataractogenesis in rats. Mol. Vis. 9, $223-230$.

Suryanarayana, P., Saraswat, M., Mrudula, T., Krishna, T. P., Krishnaswamy, K., and Reddy, G. B. (2005). Curcumin and turmeric delay streptozotocininduced diabetic cataract in rats. Invest. Ophthalmol. Vis. Sci. 46, 2092-2099.

Thiagarajan, R., and Manikandan, R. (2013). Antioxidants and cataract. Free Radic. Res. 47, 337-345. doi: 10.3109/10715762.2013.777155 
Vrensen, G. F. (1995). Aging of the human eye lens-a morphological point of view. Comp. Biochem. Physiol. A Physiol. 111, 519-532.

Wang, L., Li, C., Guo, H., Kern, T. S., Huang, K., and Zheng, L. (2011). Curcumin inhibits neuronal and vascular degeneration in retina after ischemia and reperfusion injury. PLoS ONE 6:e23194. doi: 10.1371/journal.pone.0023194

Wax, M. B., and Tezel, G. (2002). Neurobiology of glaucomatous optic neuropathy: diverse cellular events in neurodegeneration and neuroprotection. Mol. Neurobiol. 26, 45-55.

Yam, J. C., and Kwok, A. K. (2014). Ultraviolet light and ocular diseases. Int. Ophthalmol. 34, 383-400. doi: 10.1007/s10792-013-9791-x

Yang, C. Q., Sun, W., and Gu, Y. S. (2006). A clinical study of the efficacy of topical corticosteroids on dry eye. J. Zhejiang Univ. Sci. B 7, 675-678. doi: 10.1631/jzus.2006.B0675

Yue, Y. K., Mo, B., Zhao, J., Yu, Y. J., Liu, L., Yue, C. L., et al. (2014). Neuroprotective effect of curcumin against oxidative damage in BV-2 microglia and high intraocular pressure animal model. J. Ocul. Pharmacol. Ther. 30, 657-664. doi: 10.1089/jop.2014.0022

Zagon, I. S., Klocek, M. S., Sassani, J. W., and McLaughlin, P. J. (2007). Use of topical insulin to normalize corneal epithelial healing in diabetes mellitus. Arch. Ophthalmol. 125, 1082-1088. doi: 10.1001/archopht.125.8. 1082
Zhang, M., Bian, F., Wen, C., and Hao, N. (2007). Inhibitory effect of curcumin on proliferation of human pterygium fibroblasts. J. Huazhong Univ. Sci. Technol. Med. Sci. 27, 339-342. doi: 10.1007/s11596-007-0332-6

Zhang, N., Li, H., Jia, J., and He, M. (2015). Anti-inflammatory effect of curcumin on mast cell-mediated allergic responses in ovalbumin-induced allergic rhinitis mouse. Cell. Immunol. 298, 88-95. doi: 10.1016/j.cellimm.2015.09.010

Zhao, B. L., Li, X. J., He, R. G., Cheng, S. J., and Xin, W. J. (1989). Scavenging effect of extracts of green tea and natural antioxidants on active oxygen radicals. Cell Biophys. 14, 175-185.

Conflict of Interest Statement: The authors declare that the research was conducted in the absence of any commercial or financial relationships that could be construed as a potential conflict of interest.

Copyright (c) 2017 Liu, Hao, Xie, Mukhtar, Zhang, Malik, Lu and Zhou. This is an open-access article distributed under the terms of the Creative Commons Attribution License (CC BY). The use, distribution or reproduction in other forums is permitted, provided the original author(s) or licensor are credited and that the original publication in this journal is cited, in accordance with accepted academic practice. No use, distribution or reproduction is permitted which does not comply with these terms. 